\title{
ANALYSIS OF BORROWING AND REPAYMENT OF CREDIT AMONG LIVESTOCK FARMERS IN CROSS RIVER STATE, NIGERIA
}

\author{
O. G. EDET, E. E. AGBACHOM, J. A. IGIRI AND G. A. SAMPSON
}

(Received 07 April 2016; Revision Accepted 28 June 2016)

\begin{abstract}
This study examined borrowing and repayment of credit among livestock farmers in Cross River State, Nigeria. Data for the study was obtained from the Bank of Agriculture (BOA), Calabar. Descriptive statistics such as percentage count, mean and tables were employed in the analysis. It was discovered that BOA in collaboration with Women Fund for Economic Empowerment (WOFEE), National Directory of Employment (NDE), Niger Delta Development Commission (NDDC), Micro Enterprise Development Agency (MEDA) and Nigeria Cassava Growers Association (NCGA) provided high loan disbursement to agricultural businesses. In-house loan borrowed the highest amount of loan $\mathrm{A} 55,155,000$ from $2009-2014$ and WOFEE had the highest loan repayment percentage of $86 \%$. Result also shows that the total amount of $\mathrm{N} 101,456,326$ was disbursed during the period and $53.7 \%(\mathrm{~N} 52,484,619.55)$ was recovered, which shows an average loan default. The highest (79.6\%) loan repayment was made in 2012 and the lowest $(39.5 \%)$ was made in 2014 over the period. Poultry farmers received the highest loan disbursement of $\mathrm{N} 25,122,050$ and repayment of $8,219,467.93$, while fish farmers had the lowest loan disbursement of $3,770,000$ and repayment of 1,474,392.4 from 2009-2014 respectively. The study recommends among others, more supervision to loan beneficiaries so as to encourage high repayment.
\end{abstract}

KEYWORDS: Borrowing and repayment, credit, livestock

\section{INTRODUCTION}

Agriculture is the deliberate effort to modify a portion of the earth's surface through the cultivation of crops and the raising of livestock for sustenance or economic gain (Rubenstain, 2003). Agriculture can be a source of growth for the national economy, a provider of investment opportunities for the private sector, and a prime driver of agriculture related industries and the non-farm economy. Despite Nigeria's rich agricultural resource endowment, however, the agricultural sector has been growing at a very low rate. Less than $50 \%$ of the country's cultivable agricultural land is under cultivatable. Even then, small holder and traditional farmers who use rudimentary production techniques, with resultant low yields, cultivate most of this land. The small holder farmers are constrained by many problems including those of poor access to modern input and credit. (Mangong, Aikpi, Olayemi, Yusuf, Omonona, Okorua, and Idachaba, 2005). To address this problem, successive government has embarked on policies and programmes aimed at boasting sustainable agricultural productivity in Nigeria (Effiong and Onyenweaku, 2006). In spite of these efforts, the information available suggests that rural financial markets still remained under developed. A survey on household access to credit facilities in Nigeria conducted by Central Bank of Nigeria, shows that $68 \%$ of rural households had no access to credits, due primarily to low volume of business in rural areas, the processing requirements of small amounts of loan demanded by rural farmers, lack of collateral securities by most rural dwellers, low income and hence low repayment capabilities among other factors (CBN 2006). Basically, credit has been described as one of the most important factor militating against the productivity of agriculture especially among rural dwellers (Ugbajah and Chidebelu 2013). One of the reasons for the decline in the contribution of agriculture to the economy of Nigeria is the lack of a suitable national credit scheme and paucity of credit institutions (Afoliabi, 2008). Bank of Agriculture primarily is concerned with agricultural financing at both the micro and macro levels as well as micro, small and medium enterprise financing (Igwilo, 2012). Olagunju et al (2013) revealed that the major constraint to Bank of Agriculture performance included: underfunding of the Bank by the Federal Government, changes in Government policies in finances of Agriculture, frequent changes in the identity of the Bank, increase in interest rate and closure of branches, organizational factors, lack of tool and mandatory $20 \%$ deposit by the famers. Loan repayment default can be checked through a well written and descriptive criteria for borrowing. The criteria for borrowing are designed to give the highlight of what is involved in sound business borrowing. More experienced owners and manager should find it useful in re-evaluating their borrowing operations, lending institutions are not only interested in loan repayment, they are interested in borrowers with healthy profitmaking business. Therefore, whether or not collateral is required for a loan, the set loan limitation and restrictions to protect themselves against unnecessary

O. G. Edet, Department of Agricultural Economics, University of Calabar, Calabar. Cross River State, Nigeria.

E. E. Agbachom, Department of Agricultural Economics, University of Calabar, Calabar. Cross River State, Nigeria.

J. A. Igiri, Department of Agricultural Economics, University of Calabar, Calabar. Cross River State, Nigeria.

G. A. Sampson, Department of Agricultural Economics, University of Calabar, Calabar. Cross River State, Nigeria. 
risks and at the same time against poor management practices by their borrowers. (Adam 2015). In order to make loan constantly available to farmers and ensure proper or adequate funding of agriculture the government have set up specialized institution and schemes such as the Bank of Agriculture (BOA) and the Agricultural Credit Guarantee Scheme Fund (ACGSF) to ensure that farmers have access to credit at affordable interest rate, collateral and ensure simplicity on accessing loans at the right time. Guidelines have also been set up to encourage these institutions such as the Bank of Agriculture (BOA) and Commercial Banks to give credit to farmers without giving into traits of repayment inability or loan default as well as ensure that farmers have access to credit when they need without delay in processing of loans. It is appears that majority of farmers are still not benefiting from this schemes and the financial institutions are still faced with the problem of loans repayment which affects disbursement (Brown, 2008). Therefore, the study was set to analyze borrowing and repayment of credit among livestock farmers in the Bank of Agriculture in Calabar, Cross River State. The specific objectives are to; examine the disbursement and repayment of agricultural loan, determine the total amount of loan disbursement by BOA to livestock farmers and assess the total amount of loan repayment by livestock farmers.

\section{METHODOLOGY}

The study was carried out in Calabar, Cross River State, using the Bank of Agriculture (BOA), Women Fund for Economic Empowerment (WOFEE), National Directory of Employment (NDE), Niger Delta Development Commission (NDDC), Micro Enterprise Development Agency (MEDA) and Nigeria Cassava Growers Association (NCGA) as case study. The State is geographically located between latitude $4^{0} 15$ and $7.00^{\circ}$ north of the equator and longitude $7.15^{\circ}$ and $9.30^{\circ}$ east of the Greenwish meridian.it is situated in the rain forest belt. Calabar consists of Calabar municipality and
Calabar South Local Government Area. The estimated population is about 720,862 according to 2006 population census. Calabar consist of three major tribes namely; Efut, Qua and Efiks who are mostly small holder famers and traders.

The study population consists of farmers who are engaged in poultry, piggery and fishery production, and had borrowed loan from BOA from 2009-2014. Secondary data was used for the study and was collected directly from the Bank of Agriculture.

\section{METHOD OF DATA ANALYSIS}

This involved the use of descriptive statistical, using means, percentages and tables to explain the level of disbursement and repayment of loan.

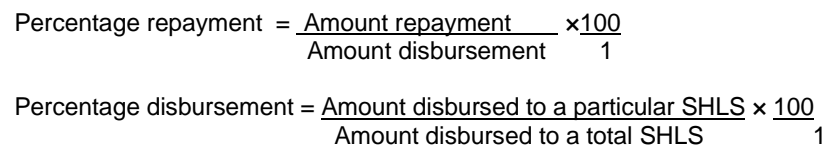

Where SHLS is Small Holder Loan Scheme

Percentage outstanding $=\underline{\text { Amount outstanding }} \times \underline{100}$ Amount disbursement

\section{RESULTS AND DISCUSSION}

Level of Disbursement and Repayment of loans under various small holder loan scheme from 2009-2014

Table 1 shows the various small holder loan scheme in Bank of Agriculture (BOA) which are In-house loan, Women Fund for Economic Empowerment (WOFEE), Nation Directory of Employment (NDE), Niger Delta Development Commission (NDDC), Micro Enterprise Development Agency (MEDA) and Nigeria Cassava Growers Association (NCGA). In-house loan disburse the highest loan amount of $\$ 55,155,000$ while NCGA disburse the lowest loan amount of $\mathbf{N 1 , 0 5 0 , 0 0 0}$

Table 1: Showing disbursement to various small holder loan scheme in bank of agriculture from $2009-2014$

\begin{tabular}{|l|l|l|l|l|l|l|}
\hline YEAR & $\begin{array}{l}\text { IN }- \text { HOUSE } \\
\text { LOAN(N) }\end{array}$ & WOFEE (N) & NDE (N) & NDDC (N) & MEDA (N) & NCGA (N) \\
\hline 2009 & $10,500,000$ & - & 700,000 & - & - & - \\
\hline 2010 & $5,000,000$ & $1,200,000$ & 300,000 & - & - & - \\
\hline 2011 & $8,700,000$ & $1,050,000$ & 150,000 & - & - & - \\
\hline 2012 & $4,100,000$ & - & - & $5,732,056$ & - & - \\
\hline 2013 & $5,530,000$ & - & - & $2,436,700$ & $23,164,450$ & - \\
\hline 2014 & $21,325,000$ & - & - & 500,000 & $10,018,120$ & $1,050,000$ \\
\hline Total & $\mathbf{5 5 , 1 5 5 , 0 0 0}$ & $\mathbf{2 , 2 5 0 , 0 0 0}$ & $1,150,000$ & $\mathbf{8 , 6 6 8 , 7 5 6}$ & $\mathbf{3 3 , 1 8 2 , 5 7 0}$ & $\mathbf{1 , 0 5 0 , 0 0 0}$ \\
\hline
\end{tabular}

Table 2 shows that there was no $100 \%$ recovery of loan by the various SHLS from $2009-2014$. The highest repayment percentage was $86 \%$ under WOFEE and the lowest repayment percentage was $45 \%$ under MEDA. The bank complained that NDDC has stop disbursement of loan in 2014 as a result of poor repayment by farmers and the repayment percentage was $76 \%$. Showing that the MEDA which has the lowest repayment percentage of $45 \%$ may withdraw disbursement if the repayment default increases.
Therefore, these shows that loan default can lead to reduction in the supply of loan to the agricultural sector.

These study agree with Brown (2008) that carried out a study on the "Efficiency Analysis of Credit Recovery by the Nigerian Agricultural Cooperative and Rural Development Bank, Calabar Branch" he concluded that between $2002-2008$ none of the loan recovery was up to $100 \%$ and therefore the rate of loan repayment by the Bank Of Agriculture (BOA), formerly NACRDB cannot be said to be efficient. 
Table 2: Showing percentage repayment in the various small holder loan scheme (SHLS) from 2009-2014

\begin{tabular}{|l|l|l|l|}
\hline SHLS & $\begin{array}{l}\mathbf{N} \\
\text { Disbursement }\end{array}$ & $\begin{array}{l}\mathbf{N} \\
\text { Repayment }\end{array}$ & $\begin{array}{l}\% \\
\text { Repayment }\end{array}$ \\
\hline IN-HOUSE LOAN & $55,155,000$ & $27,561,747.68$ & 50 \\
\hline WOFEE & $2,250,000$ & $1,936,016.44$ & 86 \\
\hline NDE & $1,150,000$ & $808,606.26$ & 70 \\
\hline NDDC & $8,668,756$ & $6,606,160.01$ & 76 \\
\hline MEDA & $33,182,570$ & $14,767,089.16$ & 45 \\
\hline NCGA & $1,050,000$ & 808,000 & 77 \\
\hline
\end{tabular}

Source: BOA (2016)

Table 3 shows that the total number of loan disburse was $\mathrm{N} 25,122,050$ and repayment of $\mathrm{N} 8,219,467.93$. The table shows that in 2013 poultry farm received the highest amount of loan which was N9,957,250 with repayment of $A 3,275,586$, followed by 2014 where farmers received $\mathrm{N8,582,000}$ and repayment of N3,154,981.93. The lowest disbursement of loan was 250,000 with repayment 216,900 in 2009 . The table showed that the highest number of loan beneficiaries was in 2013 and 2014 with 35 and 28 number of beneficiaries while the lowest number beneficiaries were in 2009 and 2011 with one (1) as number of beneficiaries. In 2009 the interest rate was 14\% while from 2011-2014 the interest rate was fluctuating between $8 \%$ and $12 \%$ within each year. The table also shows that the number of loan disburse increased as interest rate reduce. There was no loan disbursed in 2010.

Table 3: Loan disbursement and repayment by Poultry famers

\begin{tabular}{|c|c|c|c|c|c|}
\hline Year & $\begin{array}{l}\text { Noan disbursement } \\
\text { Lot }\end{array}$ & $\begin{array}{l}\text { No. } \\
\text { borrowers }\end{array}$ & $\begin{array}{l}\% \\
\text { Interest }\end{array}$ & Repayment & $\begin{array}{l}\text { Outstanding } \\
\text { Out }\end{array}$ \\
\hline 2009 & 250.000 .00 & 1 & 14 & $216,900.00$ & $227,422.29$ \\
\hline 2010 & - & - & - & - & - \\
\hline 2011 & $1,500,000.00$ & 1 & $12 \& 8$ & $1,265,000.00$ & $777,600.24$ \\
\hline 2012 & $4,832,800.00$ & 4 & $12 \& 8$ & $307,000.00$ & $5,756,112.35$ \\
\hline 2013 & $9,957,250.00$ & 35 & $8 \& 12$ & $3,275,586.00$ & $8,437,067.44$ \\
\hline 2014 & $8,582,000.00$ & 28 & $12 \& 8$ & $3,154,981.93$ & $6,386,764.37$ \\
\hline Total & $25,122,050$ & 69 & - & $8,219,467.93$ & $21,584,966.69$ \\
\hline
\end{tabular}

Source: BOA (2016)

Table 4 shows that the total number of loan disburse was

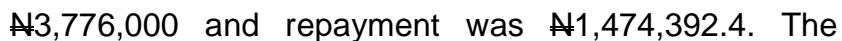
highest loan disburse was in 2014 which was $\mathrm{N} 1,100,000$ while repayment was in $\mathrm{N} 259,050$. While the lowest amount of loan disburse was in 2010 which was $\mathrm{N} 200,000$ and repayment was $\mathrm{N} 177,000$. The highest number of beneficiaries was in 2013 and 2014 which were 6 and the lowest amount of beneficiaries was 2009, 2010 and 2012 which was one (1) beneficiaries. From 2009-2014 the interest rate fluctuated between $12 \%$ and $8 \%$. There was no loan disburse to fish farming in 2011 .

Table 4: Loan disbursement and repayment by Fishery farmers

\begin{tabular}{|l|l|l|l|l|l|}
\hline Year & $\begin{array}{l}\mathbf{N} \\
\text { Loan } \\
\text { disbursement }\end{array}$ & $\begin{array}{l}\text { No. } \\
\text { borrowers }\end{array}$ & $\begin{array}{l}\text { \% } \\
\text { Interest }\end{array}$ & $\begin{array}{l}\mathbf{N} \\
\text { Repayment }\end{array}$ & $\begin{array}{l}\mathbf{N} \\
\text { Outstanding }\end{array}$ \\
\hline 2009 & $1,000,000.00$ & 1 & 14 & $786,742.40$ & $766,909.04$ \\
\hline 2010 & $200,000.00$ & 1 & 14 & $177,000.00$ & $86,104.00$ \\
\hline 2011 & - & - & - & - & - \\
\hline 2012 & $500,000.00$ & 1 & 12 & 141000.00 & $530,055.60$ \\
\hline 2013 & $970,000.00$ & 6 & 8 & $110,600.00$ & $1,031,978.50$ \\
\hline 2014 & $1,100,000.00$ & 6 & $8 \& 12$ & $259,050.00$ & $971,026.82$ \\
\hline Total & $\mathbf{3 , 7 7 0 , 0 0 0}$ & $\mathbf{1 5}$ & - & $\mathbf{1 , 4 7 4 , 3 9 2 . 4}$ & $\mathbf{3 , 3 8 6 , 0 7 3 . 9 6}$ \\
\hline
\end{tabular}

Table 5 shows total amount of loan disbursed to piggery farmers was $\$ 4,090,140$ while repayment was $\mathrm{N} 1,41,654$.3. The highest amount of loan disburse was $\mathrm{N} 2,998,140$ in 2012 with repayment of zero while the lowest amount of loan disburse was $\mathrm{N100,000}$ in 2013 with repayment of $\mathrm{A10}, 000$. The numbers of beneficiaries in 2009, 2012 and 2013 was one (1) in 2010, 2011 and in 2014 loan was not disbursed to piggery farmers. 
Table 5: Loan disbursement and repayment by Piggery famers

\begin{tabular}{|l|l|l|l|l|l|}
\hline Year & $\begin{array}{l}\mathbf{N} \\
\text { Loan } \\
\text { disbursement }\end{array}$ & $\begin{array}{l}\text { No. } \\
\text { borrowers }\end{array}$ & $\begin{array}{l}\text { \% } \\
\text { interest }\end{array}$ & $\begin{array}{l}\mathbf{N} \\
\text { Repayment }\end{array}$ & $\begin{array}{l}\mathbf{N} \\
\text { Outstanding }\end{array}$ \\
\hline 2009 & $1,000,000.00$ & 1 & 14 & $131,654.30$ & $1,622,123.65$ \\
\hline 2010 & - & - & - & - & - \\
\hline 2011 & - & - & - & - & - \\
\hline 2012 & $2,998.140 .00$ & 1 & 8 & 0.00 & $1,483,74.39$ \\
\hline 2013 & $100,000.00$ & 1 & 8 & $10,000.00$ & $107,788.89$ \\
\hline 2014 & - & - & - & - & - \\
\hline Total & $\mathbf{4 , 0 9 8 , 1 4 0 . 0 0}$ & - & - & $\mathbf{1 , 4 1 6 5 4 . 3}$ & $\mathbf{3 , 2 1 3 , 7 8 6 . 9 3}$ \\
\hline
\end{tabular}

\section{CONCLUSION AND RECOMMENDATIONS}

The major conclusion derived from the study was that there was average loan default in the bank of agriculture, and that in-house loan had the highest loan disbursement to agricultural businesses. Also collaboration with other institutions like MEDA, WOFEE, NDDC, NDE, NCGA, has brought about increase loan disbursement to farmers in agricultural businesses. The non-recovery or high loan default of agricultural loans will destroy the long run viability of the Bank of Agriculture. This is because the amount of loan available would not be enough to meet prospective needy farmers, which restrict the roles of credit to agricultural development and affect farmers' access to loan. In the light of the above, it is recommended that the bank should; ensure that farmers are credit worthy before loan is disbursed to reduce default, have a stable interest rate for a particular agric business since interest rate fluctuates within a particular year, which affect repayment, improve on the loan recovery-effort and educate farmers on the need to repay loan at the stipulated time.

\section{REFERENCES}

Adam, J. L., 2015. Development and maintenance of an effective loan policy. Retrieved from https://www.communitybanking-connections.or/a rticles/2015/development-and-maintenance-onan-effective-loan-policy.

Afolabi, J. A., 2008. Analysis of Loan Repayment Among Small Scale Famers in South WesternNigeria. A Discrimination Approach. Journal Social Science 17, (1): $83-88 . c$

Brown, A. A., 2008. Efficiency Analysis of Credit Recovery by the Nigerian Agricultural Cooperative and Rural Development Bank (NACRDB) Calabar Branch, Calabar, Cross River State. Unpublished B.Sc. Project, Department of Agric Econs \& Ext, University of Calabar.

CBN., 2006. CBN Banking Supervision annual report.
Effiong, K. M., 2006. Profit efficiency in broiler production in Akwa Ibom State, Nigeria. Global Journal of Agricultural Science 5, (1) $43-47$.

Igwilo, J. U., 2012. Assessment of Bank Agriculture Credit Delivery and Utilization Among Smallholder Farmers Awka North Local Government Area of Anambra State, Nigeria. An unpublished B.Sc Project, Departments of Agricultural Economics \& Extension Anambra State University, Igbariam.

Mangong, V. M., Aikpi, J., Olayemi, S. A., Yusuf, B. T., Omonona, V. Okorua and Idachaba, F. S., 2005. Agriculture in Nigeria: identifying Opportunities for increased commercialisation and investment. UTA, Ibadan, Nigeria. 159p

Olagunju, F. I., Akintola, L. T., Ogunniyi, L. F., Fakayodo, S. B and Babatunde R. O., 2013. Impact of Bank of Agriculture Limited (BOA) on poverty status of small-scale farm household in south western Nigeria. International Journal of Accounting and financial Management Research (IJAFMR) ISSN 2249-6882, 3, (1): 1-10

Rubenstein, J. M., 2003. The Cultural Landscape: An Introduction to human geography. $7^{\text {th }}$ ed. Upper saddle river, NJ: Perarson Education Inc. P. 496.

Ugbajah, M. O and Chidebelu, S. A., 2013. The impact of consumption behaviour on farm investment among rural farmers in Anambra State, Nigeria. In Ferej, AK and Opara, F. (eds). Proceedings of the First International Interdisciplinary Conference held at University of Eldoret, Kenya in Collaborations with Anambra State University, Nigeria. 3rd -5th September 2013. 
